\title{
Title: Vulnerable Prisoner Masculinities in an English Prison
}

\section{Abstract}

Scholarship on prison masculinities to date has primarily centred on the most revered, dominant or hegemonic forms with little attention to how subordinated prisoners negotiate masculinities at the bottom of prisoner hierarchies. This article, drawing from a wider qualitative study on 'revolving door' imprisonment, charts the shift from normative to subordinate masculinity for a group of men housed in a segregated Vulnerable Prisoner Unit (VPU ${ }^{1}$ ) in an English prison. I show how these men, influenced by their previous prison status and criminal history, adopted different, more costly and high-risk, situationally-adaptive strategies in negotiating their masculinities at the bottom of prison hierarchies. Exploring their subordinated prison identities reveals the dynamic, relational, fragile and spatial elements of their masculinities. I conclude by suggesting that a greater focus on subordinated carceral masculinities adds a much-needed divergence from the preoccupation with hegemonic or dominant prison masculinities. This divergence offers researchers a new opportunity to shape and to inform policy debates on how, in extreme environments like the prison, alternative ways of 'being a man' might be opened up to those who have suffered at the most brutal end of prison hierarchies

\section{Key words}

prison; prisoners; space; inmate code; hegemonic masculinity; vulnerability;

\section{Introduction}

Prisons and prisoners are not homogeneous entities or groups. Classic prison sociology (Clemmer, 1958; Irwin \& Cressey, 1962; Sykes, 2007) and more recent works exploring prison masculinities have shown how prisoners are stratified or hierarchically-organised according to their crimes, masculine conduct in prison, and 
I or their status and reputation imported from outside (Carlsson, 2013; Earle, 2011; Evans \& Wallace, 2008; Phillips, 2012). This prison scholarship has largely focused on the most revered, dominant or hegemonic forms with little attention to how subordinated prisoners situationally negotiate masculinities at the bottom of prison hierarchies. The experiences of these men are equally important to understand. As Rosemary Ricciardelli et al. (2015) note, hegemonic masculine forms are reciprocally connected or dependant on these under-studied marginalised masculinities. Drawing on Raewyn Connell's concept of hegemonic masculinity (Connell, 2000; Connell \& Messerschmidt, 2005) - one that recognises a situationally configured plurality of masculinities, based on relations of domination and subordination - this paper focuses on those who fail to sustain, or to live up to, revered prison masculinities. In much of the staggering body of scholarship influenced by Connell's framework, as with prison research in this area, the fixation tends to be on hegemonic or other dominant forms of masculinity, this fails fully to utilise the hierarchical aspect of the concept (Bartholomaeus \& Tarrant, 2016), and offers only a limited or obscured picture of masculinities and gendered power relations between (marginalised) men.

Responding to this dearth of enquiry on the situational configuration of masculinity among subordinated men, this paper charts the carceral gendered trajectories of a small group of low-status prisoners. The focus is not on prisoners who - due to the nature of their crimes (usually people who have been convicted of sexual offences) - start out and remain at the bottom of prison pecking orders (see Levins \& Crewe, 2015), but on those who fail to establish, or struggle to sustain, respectable prison masculine identities and have consequently been forced to the subordinated end of prison hierarchies. Showing the fragility of prison identity and the all-too-easy shift from normative to subordinate masculinity, I map the gendered 
experiences of ten prisoners. Eight of the ten prisoners had been formally assessed and categorised as being Vulnerable Prisoners - they had consequently been segregated from the main prison population on a Vulnerable Prisoner Unit - while the remaining two prisoners had resisted this official label, instead adopting high-risk strategies known in prison argot as 'blocking off' and 'blending it' as a means of navigating a liminal space between main location and the VPU. The key question is: how do male prisoners negotiate masculinities across extreme and hostile carceral spaces - including the segregated Vulnerable Prisoner Unit - and within (and against) the official and highly denigrative category of 'Vulnerable Prisoner'?

In negotiating masculinity at the bottom of prison hierarchies, I show how these men, drawing on their previous prison status and criminal history, employed the following distinct but overlapping forms of situationally-adaptive masculine strategies: adaptation through (overt) narratives of resistance; through subverting dominant prison masculinity; through pragmatism and, as mentioned earlier, 'blocking off' and 'blending'. I conclude by arguing that further research into the configuration of subordinated masculinities might well show similar strategies among men who are situated low down in the status hierarchies of other extreme or challenging (mostly) male environments in the military, sport and other work spaces. Increased focus in this area has the potential to encourage broader policy debates and attention on how alternative or healthier avenues to being men might be opened for those brutalised and subjugated in the pursuit of the hegemonic ideal.

\section{'Prisoners as men'}

There is a rich body of classical sociological studies on prisons, either centring on debates which claim that prison culture and identities are generated through adaptation to the deprivations of the carceral space (Clemmer, 1958; Morris \& Morris, 
1963; Sykes, 2007) or, by contrast, importation debates which suggest that street criminal hierarchies seamlessly import into the prison (Irwin \& Cressey, 1962). Although much of this classical penal scholarship has recognised that it is men that fill prisons, the gendered aspects were practically invisible. In deeply masculinised penal spaces, both importation and adaptation proponents too readily overlooked questions of masculinity. To move beyond this, Joe Sim proposes that there needs to be much more critical analysis of 'prisoners as men' (1994, p. 100). Viewing classical penal scholarship through a gendered lens, hierarchised forms of masculinities and the role of carceral spaces in the situational reproduction and configuration of revered and subordinated masculinities are easily identified. Importation scholars, for example, hailed the 'thief' as the 'solid' and 'good convict', his revered masculine identity firmly at the top (Irwin \& Cressey, 1962). Deprivation proponent, Gresham Sykes, similarly notes that, in prison, the 'real man' is he who 'embodies the inmates' version of decorum', 'pulls his own time' and 'confronts his captors with neither subservience nor aggression' (2007, p. 102). These exalted prison masculine identities were contrasted and configured against subordinated groups such as the 'stool pigeon' or 'rat' (informer) and those at the bottom: rapists and other predatory sex offenders, particularly those who had harmed children (Clemmer, 1958; Irwin \& Cressey, 1962; Sykes, 2007).

\section{Hegemonic masculinity}

Raewyn Connell's theory of hegemonic masculinity is well suited to analysing relations of domination and subordination among men in prison through a gender framework (Connell, 2000; Connell \& Messerschmidt, 2005). Adapting Antonio Gramsci's (1971) concept of hegemony - an idea that denotes the cultural dynamic by which one class sees subordination by the dominant class as 'natural' - and 
applying it to masculinity, she posits that the hegemonic version of masculinity in any given pattern of gender relations is concerned with maintaining hierarchicallyorganised power relations between men and women as well as - importantly, here between men themselves. Hegemonic masculinity, Connell is clear, cannot be understood in a statistical sense as most will never fully live up to the hegemonic ideal. But it is nevertheless normative: all men, to some extent, position themselves in relation to it, and in doing so are complicit in the hegemonic project (2000).

Hegemonic masculinity is understood as the most honoured way of being a man and is distinguished from, and in competition with, what Connell terms subordinated masculinities (i.e. gay, effeminate, weak, economically poor and minority ethnic groups). As well as proposing a plurality of masculinities and capturing gendered power dynamics between men, further analytical purchase from this framework is that it recognises hegemonic masculinity is not fixed in time and space. Connell and her long-time collaborator James Messerschmidt acknowledge 'empirically existing hegemonic masculinities' at the local, regional and global levels (Connell \& Messerschmidt, 2005, p. 849). Although influenced by the regional and the global, the 'local' captures variations in the forms of hegemonic and marginalised masculinities that exist in different localities, sites and spaces, such as prisons.

Hegemonic masculinity has come in for some criticism (see Beasley, 2008; Collier, 1998; Hood-Williams, 2001; Jefferson, 2002), a major issue being that it negates internal processes or the role of the psyche in (male) identity (Hood-Williams, 2001; Jefferson, 2002), and for Richard Collier (1998) it reduces the complexity and nuances of what men actually do to simplistic and static typologies that tend only to emphasise the negative traits of manhood. In their (2005) paper, 'Hegemonic Masculinity Rethinking the Concept', Connell and Messerschmitt adjust the concept 
in light of some of the limitations identified and, at the same time, comprehensively respond to many of their critics. While acknowledging these debates, Connell's framework is best placed to offer analytical purchase on how space, criminal and prison cultures and other categories of identity (age, race, sexuality etc.) intersect to generate a plurality of masculinities and to reveal the mechanisms behind the positioning of subordinate and dominant groups that make up prison masculine hierarchies.

Don Sabo's, Terry Kupper's and Willie London's Prison Masculinities (2001) is one of the first edited collections on men, masculinity and prison in which a number of contributors have drawn heavily upon the concept of hegemonic masculinity. Writing predominantly from an American penal perspective and sharing many parallels with the classic penal scholars, the main theme running through most of this collection is how masculinities are stratified around adherence to, and the policing of, a universal underworld / inmate 'code'. First identified in classic penal scholarship through the work of prison sociologist Donald Clemmer (1958), and later developed by others (Copes, Brookman, \& Brown, 2013; Trammell, 2009), the core ethos of the inmate code centres round not cooperating with 'government officials in matters of discipline' and to never give information of any kind, 'especially the kind which may work to harm a fellow prisoner' (Clemmer, 1958, p. 152). Other important elements of the code relate to the overt rejection of, and often violent policing of, perpetrators of taboo crimes (usually predatory sexual offending or crimes against the vulnerable - women, children and the elderly), and 'doing your own time'. In his chapter for Prison Masculinities, Kupers (2001) argues that adherence to and enforcement of this code is what marks a sharp line between those prisoners who are at the top and those who are at the 'feminine' defined bottom (ibid, p.115). An 'enduring 
commandant' of the code is: 'Thou shalt not snitch' (ibid, p.119). To go against this, he writes, can carry a 'death penalty'. Violations of the inmate code are widespread, but its potency is seen, according to Kupers, (2001), in the way it controls others and defines revered and subjugated masculine conduct.

Writing from a U.K. perspective, Sim (1994) emphasises how the penal space contributes to the type of masculine identities configured, and that hierarchies are built on complex horizontal and vertical dimensions of power. Dominant or revered masculinities held by both prisoners and male staff, for instance, will be very different in a low-security open prison to those found in the high-security prison. Studies show that the particular age or stage of life of prisoners, and how it intersects with the type of carceral space, is also important. Masculine performances that are found among adult male prisoners are much less extreme than the hypermasculine identities (achieved almost daily through violence and fighting prowess) that are found in young prisoner establishments (Gooch, 2017; Tynan, 2019). Among adult 'cons', engaging in this constant, unpredictable and futile violence is often seen as a sign of immaturity and is perceived as an indicator of one's inability to handle doing their time (Crewe, 2009; Evans \& Wallace, 2008). As Yvonne Jewkes (2005) found, young men enter (adult) prison and attempt to assert 'hard' masculinity - but are often dismissed as 'wannabe gangsters' by the older long-termers; often 'lifers' and armed robbers who are equally keen to express and to maintain the revered masculinity of the proper 'villain'. The defining characteristics of hegemonic prison masculinity as shown across this literature, then, are: stoicism; having no history of informing or 'wrong un' offences (usually against the elderly, children and other vulnerable victims); an ability to stand up for oneself - often through a measured display of aggression and violence; showing respect to, and commanding the respect of, fellow prisoners and 
staff; an ability to be self-sustainable; maintaining high personal and cell hygiene; and outwardly showing that you 'can do the time' (Evans \& Wallace, 2008; Gooch, 2017; Jewkes, 2005; Ricciardelli et al., 2015; Sabo et al., 2001; Sloan, 2012; Tynan, 2019).

\section{Subordinated masculinities}

This scholarship and much other work on carceral masculinities has certainly opened up the interrogation of prisoners as men. However, it has concentrated on hegemonic/ hyper/ dominant prisoner forms, with only scant attention paid to the configuration of masculinities of subordinated identities. If, as has been show, all male prisoners cannot sustain hegemonic or dominant forms of at all times, then the omission or lack of focus on how those men at the bottom of prisoner hierarchies negotiate masculinities suggests that much existing research offers only a partial and oversimplified - or even obscured - picture of gender relations among prisoners. There is some limited discussion that better accounts for the fluidity and fragility of prison masculinities, and shows wider recognition of more nuanced, complex and dynamic relations of dominance and subordination among male prison populations. Highlighting the gendered vulnerabilities of male prisoners, Hans Toch (1998) identifies how prison traps men in hypermasculine performances, long after they can meet the criteria for this identity. The late realisation of their inability to measure up to manhood ideals leads many to a terminal emotional state: a kind of masculine bankruptcy which commonly manifests itself, he writes, in depression, self-harm, increased drug and alcohol abuse, or - as shown by the cases of the respondents featured here - their formal classification as 'vulnerable'. For Toch, this low point can prove a vital time for working with men who might well be more receptive to exploring alternative avenues to 'doing masculinity'.

Prisons generate high levels of risk that endanger prisoners physically 
(sometimes fatally) and emotionally(Ricciardelli et al., 2015). In recent research, Ricciardelli and colleagues (2015) found that the overriding feature of prison life is the management of risk and the accompanying fear attached to everyday events and encounters. Masculinities, they show, were strategically configured as a response to the 'fluid characterisation' of risks, to 'vulnerabilities' (physical and emotional) and to penal uncertainties; in this process, the prisoners both simultaneously reproduce and destabilise masculine ideals (ibid, p. 493). Physical vulnerability, for instance, associated with feelings of 'insecurity, powerlessness and a lack of control, reinforces forms of aggressive and stoic masculinities' (ibid, p. 503). At the same time, these masculine performances generate a culture of violence, increasing the risk of attacks and amplifying vulnerabilities.

In his research with English prisoners, Nick De Viggiani (2012) described how this survival strategy of conforming to normalised stoic masculine personas - doing your time like a 'real' man by projecting physical, psychological and emotional strength - leads to significant harm. Not wanting to risk compromising their masculine identities, male prisoners, he found, avoided support for emotional and mental health problems, neglected medical advice for physical complaints and regularly rejected efforts to improve themselves intellectually and vocationally, thereby increasing the likelihood of their returning to prison. The suicide rate among male prisoners (in England and Wales) being six times greater than that of the general population (Fazel, Ramesh, \& Hawton, 2017) shows just how extreme the prison environment can be. The insidious stoic masculine survival strategy adopted by prisoners as a means of navigating penal risk - by cloaking struggles under 'man up' and violent performances (De Viggiani, 2012; Ricciardelli, 2015) - is clearly not an effective nor an available strategy for many men, and serves to profoundly amplify and to add to 
the pains of imprisonment. In these carceral spaces, where masculinities have to be continuously achieved and are constantly contested, it is he who can appear to be 'the least physically, emotionally and legally vulnerable, and is best able to manage the uncertainty of prison life' (Ricciardelli et al., 2015, p. 492) who epitomises hegemonic masculinity. This article shows the difficulties that many prisoners experience in maintaining this normative position: the ease with which the strategy of shrouding one's physical and emotional fragility can fail, and the resulting slide to embodying subordinate masculinities that follows.

\section{Methods}

\section{Field}

The findings discussed here are taken from a larger research project which explores the classed and gendered trajectories that have led to 'revolving door' imprisonment for a group of men held in a medium to high security local prison in East Yorkshire, England. The function of a male local prison is to serve designated courts within a particular catchment area, holding those who are on short sentences, who are awaiting trial or sentencing, and those who are awaiting allocation to another establishment. This prison served predominantly white catchment areas; this was reflected in the research, with all participants identifying as white. This establishment housed and delivered treatment programmes for a high number of convicted sex offenders who were usually segregated in a Vulnerable Prisoner Unit with other men who have been deemed as being at risk of facing retribution from the general population for a variety of reasons

\section{Participants}

Participants' experiences are taken from a small case study sample of ten men (aged between 21 and 44 years old), eight of whom were officially categorised as 
Vulnerable Prisoners (VPs) and were accordingly housed in the VPU. The category of VPs can include anyone from men who have been convicted of rape or murdering children to those who have been accused of being informers, or who have simply run up prison debts. These men were selected because of their experiences doing time both on main location and in the VPU. The two other respondents were selected because of their experiences in struggling to navigate normative prison masculinities, and who were just on the margins of the main population as well as, arguably, being on the verge of having to be segregated for their own protection. All participants were fully briefed about the aims of the research, and assured of confidentiality and anonymity.

\section{Data and analysis}

In-depth interviews generated the bulk of the data, backed up with partial participant observation of the prison wings (tiers) and the training and education workshops. Following Connell (1995), interview data was thematically analysed. Distinct collective themes were indexed and listed under main headings that correspond to key sites in the formation of their masculinities (streets, schooling, local prison, main location, and the VPU). The analysis sought to uncover elements that contributed, individually and collectively, to the 'making and un-making of masculinity' in and against various structures, spaces and institutions (ibid, p. 91).

\section{Findings}

\section{Vulnerable masculinities}

The men featured here mostly fitted with what Toch (1998) and others (Irwin, 1970) have described as 'state raised youth' or what Jack Abbott calls 'state raised convicts'(1982). All of them came from similar highly-deprived environments or council housing estates, where a great deal of time was spent on the streets running 
with elders, in mainly all-male peer groups. Describing themselves as 'being off the rails' or 'out of control', half were taken into local authority residential children's homes during their early teens. The majority reported being excluded and/or removed from mainstream schooling and placed in specialist residential units or exclusion centres. ${ }^{2}$ Schooling was interrupted when - as children (aged between 14 to 17) - most (eight of the 10 men) had received their first prison term. Across these sites of extreme exclusion, from childhood through to adulthood, the pressures of navigating and sustaining normative masculinities - with all of their intrinsic contradictions, fragilities and challenges - proved to be too much for this cohort. At various stages in their criminal and prison journeys, their alleged shortcomings in meeting masculine ideals were exposed and - following the emasculating process of being formally categorised as 'vulnerable' by prison officials - their positions near the bottom of prisoner hierarchies were confirmed.

\section{Situationally stratified VPU masculinities}

The reasons as to why these men went from being mainstream prisoners to sharing the VPU with the sex-offender population varied. All were deemed, however, to have gone against, or to have been in breach of, the inmate code (see Clemmer, 1958; Copes et al., 2013). None identified as, or were labelled, 'sex offenders' by other VPs. Mostly, they were believed to have informed or 'grassed', with two of this group being suspected of committing crimes against 'their own' - which is to say, bigger and better-connected criminals - and, therefore, faced serious risks in the form of retribution.

Among all lower status prisoners, there is still a lot of hierarchical movement as multiple masculinities are similarly configured through the relations of domination and subordination that are found among the main population. In their paper exploring the 
situational construction of prisoner identities among sex offenders, Levins and Crew (2015) report subdivisions wherein rapists of women were positioned above those who sexually assaulted children. Similar stratifications, as I discuss in more detail shortly, were identified among these respondents as they attempted to salvage some sense of previous respectable masculine prisoner status. Within this cohort, the existence of intra-group masculine power struggles did not detract from clear collective and individual strategies adopted by these prisoners to try and resist their continuously being lumped together - by officers and main location inmates - with the 'beasts' and 'nonces' with whom they shared the Unit. Alert to their inferior positioning, most in this group spent a great deal of effort in configuring masculine identities through opposition, denigration and separation from the 'other': the predatory sex offender, who occupies a still-lower status in prison hierarchies. This strategy of separation and stratification at the lower end of prison hierarchies generated a form of solidarity among this VP cohort, as one of them, Scott, commented:

..paedophiles seem to know who the other dirty fuckers are. ...the others they call them debt heads ${ }^{3}$.. you've got them and ... the non-sex offenders like me, who stick together. (Scott)

On the whole, this group - entirely consistent with main population values - felt that they held moral superiority over the other inhabitants on the Unit. As I go on to show, this othering and dominance over the sex offenders, or 'beasts' and 'nonces', proved to be a valuable resource that allowed a number of the participants to salvage some sense of their previous masculine status.

This pull to reinstate and to reconcile some sense of pre-VPU masculine positioning with their current status contributed to intra-power struggles within the VP cohort. Resources that are valued and held on the main location, such as fighting 
prowess and criminal reputation, are imported onto the VPU, thereby generating higher or lower masculine status among this group. One of the youngest VP participants, Geoff - who was awaiting trial, accused of the murder of a local hardman - was keen to communicate his masculine credentials and 'top dog' status within this group and on the Unit:

..the person you interviewed yesterday, I've offered him out three times. He thought he was the top dog on the wing and I offered him out in front of everybody on the wing just to show that he would back down. (Geoff)

Geoff's decision to publicly challenge Jack, the only other potential rival in a power struggle among this VP cohort, was a clear strategy of both communicating his dominance and salvaging his masculine status, predicated upon his previous underworld activities and connections.

\section{VPU adaptation strategies}

In response to 'fluid characterisation' of risks, 'vulnerabilities' and penal uncertainties' (Ricciardelli et al., 2015), prison masculinities are constantly shifting. However, in exploring how prisoners both import and adapt masculinity to the profoundly denigrated carceral site of the VPU, three distinct categories of adaptation stood out. Although there is some inevitable overlap between them, they can - for analytical ease - be termed: protest adaptation; subversive adaptation; and pragmatic adaptation.

\section{Protest as adaptation}

Geoff and Jack, as seen from the extracts below, were the main 'heads' or 'faces'4 among this cohort. Both claimed to have well-established pre-VPU reputations and solid criminal credentials:

...I've been to two category A [high security] prisons, I've done about five category B prisons, all long-term....I went on the roof in one jail, dirty protests. I've been caught with mobile phones and drugs, I've been shipped out for assaulting a member of staff in another prison, so a lot of people knew me.... (Jack) 
...I've got bounties on my head... people are trying to do me in.... kind of hit man got himself arrested and it was to do with me... it's exciting for me with someone trying to do me in. l'd love to see them try (Geoff).

These 'solid' prisoner and gangster masculine narratives - while being under protection in the VPU - are fraught with contradictions and tensions that will not be immediately obvious to those outside prison and criminal cultures. To live among 'beasts' and 'child rapists', and to take official protection from the prison - regardless of circumstances, and despite past criminal exploits and hierarchical positioning erodes any previously revered masculine status. In the eyes of those who inhabit this world and appear to live by the inmate/ criminal code, both have shown extraordinary weakness consistent with subordinated masculinities.

In the relatively small pond that is the VPU space, Geoff and Jack played up to, and generated, significant masculine capital from being the 'big fish'. Yet, key to maintaining this gender identity was, largely, reliant on importing or salvaging aspects from their previous masculine status, and mostly performed through their overt protest at being on the unit and their denigration of the 'other' with whom they were 'forced' to live. Both were keen to demonstrate their resistance. Jack reported that he is regularly warned and sanctioned for calling sex offenders "dirty paedophiles, nonces...', and for expressing his hatred of being forced to 'live with these monsters' - as well as for sharing his 'disgust' for them to their faces. He noted that his uncontrolled hatred has, on occasion, seen him moved to the punishment block for cooling-off periods. Similarly, Geoff's resistance was noted through disgust and shame: 'I believe there should be a death sentence for paedophiles because paedophiles can't change....disgusted...I am embarrassed, so embarrassed.' Both spent a great deal of the interview recounting their acts of resistance while on the Unit, and claimed little agency or choice in their current formal status as Vulnerable 
Prisoners. This emasculating identity was imposed, they claimed, either due to prison protocol or because of circumstances beyond their control. They shared the difficult realisation that there is little chance of a return to their previous prison identities. Importantly, Geoff and Jack's experiences highlight the fluidity of carceral masculinities, and show how easily even a higher-status masculinity can the flow downwards to the lower end of prison hierarchies. However, once at or near the bottom, fluidity is significantly restricted as movement back upstream to any previous status is highly unlikely.

\section{Acceptance as adaptation}

Dilan's and Brian's shared adaptive strategy directly contrasts to that of Jack and Geoff. Both describe having had difficulties and having struggled among the main population for some time before accepting protection from the prison. Brian explains that his troubles started back in 2000 after a 'pad'5 got searched for drugs and he was implicated in tipping off the officers about the contraband. He had 'been coming over here ever since'. Dilan talked of being just 16 when he was put in with a much older cell mate 'with mental health problems' and describes being woken by him in early hours 'bullwhipping' him in face with a wet towel, whilst laughing hysterically. Out of sheer terror, Dilan asked for a cell move, indicating that he was not getting along with his cellmate. Officers were not so subtle with Dilan's complaint and, from that point forward, as he explains, he was shrouded in suspicion of being an informer and lived with the constant fear of being called out:

I've always worried that somebody's going to say something to me, and I start going bright red and it will be for fight or flight, which in most cases is fight and when you get older you can't be arsed with all that, that's why I'm on here now (Dilan).

It took six more years of coming in and out of prison - and a particularly brutal incident involving drugs - before Dilan's resilience wavered and he asked for protection 
status. Word got out on the main wing that Dilan had returned from a visit with a large parcel of cannabis secreted in his anal passage. His breaking point, Dilan reports, was when a mob barged in his cell, held him down and tried to forcibly remove a parcel with a spoon, known in prison argot as 'spooning'. He explains that 'they would come and try it again' and 'got sick of it so I thought fuck it'.

Dilan and Brian had served a considerable portion of prison time as Vulnerable Prisoners, segregated on the VPU. Unlike the other respondents, in what arguably can be interpreted as an act of subversion, both openly rejected main location prison culture and the resulting prison masculine hierarchies that position them as subordinate, going as far as to suggest that 'it take balls to do prison this way':

...it like undermines me, it's like you're weak, you've gone on there because you're weak and you can't hack it out on the mains, which, in a way, it is a way out. I put my hands up I couldn't.... I'm on here because I've had a hard time, I've been turned over and all the rest of it, people jumped on me. I'm on here for an easy life at the end of the day. I think most of them given the choice out there, if they had the balls, would be on here as well. (Brian)

Brian and Dilan accepted that they struggled to live up to mainstream prison masculinities and found it a relief to be off the 'mains'. Brian went as far as rejecting the futile jostling for position in the main part of the prison, and saw the acceptance of vulnerability as an act of courage and resistance against dominant prison identities. Their strategy of adaptation was one of subverting the vulnerable category to instead suggest courage and resistance. They reasoned that doing time among the sex offender population - who are not as invested in prison hypermasculine culture, and, as others have shown, are usually much older, middle class and less likely to be embroiled in illicit drug use / dealing and the disputes that follow (Levins \& Crewe, 2015) - makes for easier and 'chilled jail time' .

The inmate code that so powerfully shapes masculine identities on the mains, has much less purchase on the VPU. For most VPs, keeping the peace and one's 
place on the Unit is paramount, and so sharing information with staff or 'grassing' is the norm. This almost complete inversion of the code and shift in prison culture is disorientating and shaming for those like Jack and Geoff, but came as relief for Brian and Dilan. It is worth cautioning against overstating Brian's and Dilan's agency in opting out of these mainstream power struggles for the relatively drug and hypermasculine-free VPU. Both claimed to have been forced into taking VP status through staff incompetence or betrayal. It is more accurate to suggest that their strategies of adaptation to vulnerable status are linked more to their pre-prison / criminal masculine identities being far less established than those of Jack and Geoff.

\section{Pragmatic adaptation}

The remaining four of this VP cohort were pragmatic in how they adapted to the Unit and configured their masculinity against the formal category of vulnerable. A key strategy was to avoid acknowledging the predatory crimes of the 'others' as well as sources like newspapers and other forms of media that might expose the type of men among whom they were living. For Malcolm, 'it is not too bad....don't get me wrong, I don't want to know what they've done regarding children and stuff like that...put it into the back of your mind, what's the point, just forget it.' He goes on to say that if he, the lads, and the staff 'thought about it too much it would drive them mad'. Similarly, Lance says that it is 'that mentality that if you don't know what they're in for you can turn a blind eye, when you know what they're in for it's a different ball game'. The difficult times in the Unit, he observes, are when the crimes committed are exposed as being so awful, that it is impossible to deny the type of predatory men they are 'tarred' and among whom they are forced to live.

When you find out what they're in for, read it in the paper and then you know and you see them on the landing you just want to crack them, you want to leather them up and down, but then you're just causing more trouble for yourself...you've got to learn to live with them, when it's people that you 
shouldn't be living with, you shouldn't have to be nowhere near them, but unfortunately you are (Lance).

Among this pragmatic category, the suppressing of the masculine obligation or compulsion to act was justified in terms of self-preservation. Deeply ingrained masculine notions of the protector of the weak, women and children are well documented (see Fine, Weis, Addelston, \& Marusza, 1997; Segal, 2007), as is the expectation in criminal and prison culture to practise retribution against those who commit predatory offences against the weak, innocent and defenceless (Crewe, 2009; Hobbs, 1997). For these prisoners, however, it was not worth the risk of facing sanction or of compromising the protective space. Wayne - a respondent who is arguably more intuitive to the function of the 'other', or of the role of the subordinated in gender configurations - comments:

sexual offenders, people who tell tales and people in debt who go to protection wings, VP wings, are looked upon as scum. I mean there is always the argument that we all need somebody to look down on (Wayne).

As much as they try to deny their surroundings, the respondents have to face the daily and emasculating reality of what it means to be Vulnerable Prisoners. From the moment that these men wake, they are reminded of their vulnerability and segregation. The whole prison regime, and all movements, centre upon protecting them from the main population. The relief or joy of being visited by a loved one usually scheduled at different times and segregated from the main population - is marred by the constant abuse that they face when being escorted to and from the visit centre, as Scott explains below.

..we all get called, we get threatened, when we are moved around the prison there's those that throw things out of the window at you: 'who'd visit you, you fucking beast' and all that - 'nonce', .. I just cover myself and look the other way, it sickens me. I'm a grandad and I've got a daughter (Scott)

All movements of prisoners going to and from work and education are managed to allow VPs to be moved first, and to be safely back on the wing before mainstream 
men are free to return to their wings. Gym visits, healthcare appointments and so on are often secondary, timetabled to fit around segregation from mainstream prisoners. Even when on the Unit, and despite their pragmatism at dealing with neighbours, they are reminded of their inferior prison identity:

I don't like the term vulnerable....you feel ashamed I guess, .. unless an officer knows you and knows what you're in for, they just treat you the same.....(Ken)

\section{Subordinated liminal prison masculinity}

The empirical focus, up until now, has been upon the men who are officially categorised as Vulnerable Prisoners and are segregated in the VPU. The main argument presented here is that, across all penal spaces, male prisoners negotiate a dynamic, precarious and liminal existence between subordinated and normalised prison masculinities. In prison, manhood is a tenuous condition that is always subject to being lost (Kupers, 2001) and, as shown in the following two cases studies, lowerstatus prisoners on main location are at the sharp end of this prison reality. They

utilise a whole spectrum of high-risk and extraordinarily dangerous adaptive strategies so as to avoid being culturally and institutionally emasculated. In prison argot, they have adopted what is known 'blending it' and 'blocking off' to stave off a highly-denigrated and subordinate vulnerable status.

'Blending it' describes how some try to continue to 'blend' into, or perform, mainstream prison identities even when their behaviour or offence, if exposed, would be deemed to have gone against the criminal / inmate code and fallen short of expected masculine conduct. In attempts to fit with normalised prison masculinity, they hide or deny code breaches and amplify their criminal and prisoner credentials to present a more acceptable front stage performance (Goffman, 1969; Jewkes, 2005). Paul, not in the VP cohort but part of the wider study, revealed during interview that he had informed or given a witness statement against an individual who had 
brutally assaulted him, and that this had culminated in the perpetrator being sentenced to years in prison. He accepted that this marks him as a 'grass' or 'informer' but - rather than take up VP status and live with 'nonces' under the protection of the prison - he took the potentially deadly strategy of 'blending' in with the general population. As Paul continued with the interview, he casually stated that, during a previous prison term, the individual against whom he gave evidence was in the same jail and that - to avoid bumping into him and fighting every day - he took decision to go on 'protection' and 'keep a low profile' until his attacker was moved on.

Others in the VP cohort were clear that once it is 'out there' that you have taken 'protection' from the prison, a return to main location, even under a new prison term, is both incredibly dangerous and doubtful to last. Unlike Geoff, Jack and some of the other respondents, Paul's relatively unknown criminal / prisoner status is perhaps why, at least up until the time of being interviewed, he had been able to successfully 'blend' it. Carrying the emotional stress and daily fear that he might be found out at some point was, for him, preferable to dealing with the emasculation, shame and humiliation that comes with living in the VPU. As he explains:

We can see the VPs out the window and so all it takes is for me to be on VP and someone spot me from my area and that's it. It gets spread around the town that I was on the VP and everyone will start, because VPs are rapists and sex offenders, that's what l'Il get associated with. l'd rather risk it on here (Paul).

Another high-risk and costly strategy for preserving main location masculine status and for dealing with the threat of serious violence is 'blocking off', or intentionally going against prison authority / discipline to instigate being 'dragged' off and put in the punishment 'block' or 'segregation unit' and, consequently, out of harm's way. Isaac explained how, whilst in prison, a long way from his own local, he found himself in a position in which he felt that 'blocking off' was his only option. He told how he 
was confronted on the wing by a mob who accused him of robbing an elderly relative of another prisoner.

... he said you robbed my uncle ra ra ra. .. it genuinely wasn't me...I don't rob old people. He said I am getting you stabbed up.... I thought fuck this I don't know where this knife is going to come from....shut my door, packed all my stuff up and then got opened up for dinner and then a lad come in and stabbed me. It was only in the leg, but I thought fuck this, it's not going to end here, and so I smashed my pad up and a screw came up I kicked the door in his face and said take me down the block. ...then they shipped me out.... (Isaac)

Having spent much of his life in and out of prison, Isaac was only too aware of the danger of being associated with crimes against the elderly; he knew that asking for protection from the prison would only add credibility to the allegation, thereby serving to further emasculate him and to profoundly shift his prison identity. 'Blocking off' proved to be effective, the punishment block, housing unruly and high-risk / security prisoners, is a very different penal space to the VPU. Inmates are usually kept in solitary confinement, with the added loss of most privileges and remission. These are sacrifices that, for Isaac, were preferable to being formally labelled as 'vulnerable' and informally as a 'wrong un'. In this way, he not only preserved but likely enhanced his prisoner masculine status.

\section{Conclusion}

The centring, here, on subordinated vulnerable carceral masculinities adds a muchneeded broadening of debates from the preoccupation with hegemonic, hyper or dominant forms found in much of the existing scholarship on prison masculinity. Fully utilising Connell's hierarchal concept of hegemonic masculinity to focus on subordinated identities confirms the widely reported dynamic, relational, fragile and spatial characteristics of (prisoner) masculinities. What is shown here in detail, however, is how - within extreme penal spaces - prisoners adjusted and adapted to the all-too-easy shift from hegemonic or dominant status to varying levels of 
subordination. Importantly, the experiences of these low-status prisoners reveal the limitations to this fluidity and the ease with which flow goes down prison hierarchies; once a low point of (VP) subordinated identity is reached, a return back up to previous status is unlikely. Isaac's 'blocking off' and Paul's 'blending it' - living in constant risk and fear of being recognised and exposed as being in breach of the inmate code, and forced into VP status - indicate that they are profoundly attuned to the costs and risks of this masculine relegation. The adaptation strategies of this VP cohort drew heavily on their masculine status in previous carceral journeys and criminal backgrounds. Those who had less masculine capital prior to being categorised as Vulnerable Prisoners adapted more easily to their subordination, with some actively embracing their position and rejecting hegemonic prison masculinity.

In the 1990s, Toch (1998) called for penal spaces that work better by making the first move to facilitate an environment in which men may take up a 'reparative script': one that offers a way out of their struggle for a masculine identity to which they can no longer live up. The men featured here, having failed to live up to normative prison masculinities, were evidently ready for something different. Unfortunately, the only pathway open to this subordinated group in this local prison was not a reparative one, but one loaded with risk, fear, failure, loss, shame, trauma and guilt. With more focus on the situational configuration of gender among such subordinate groups, penal scholars can better help to shape and to inform policy debates on how - in extreme environments like prison - alternative or reparative avenues might be opened up to those who have contributed to and suffered at the most brutal end of prison hegemonic masculine performances. 


\section{References}

Abbot, J. (1982). In the belly of the beast. Vintage Books.

Bartholomaeus, C., \& Tarrant, A. (2016). Masculinities at the margins of "middle adulthood": What a consideration of young age and old age offers masculinities theorizing. Men and Masculinities, 19(4), 351-369. https://doi.org/10.1177/1097184X15588592

Beasley, C. (2008). Rethinking hegemonic masculinity in a globalizing world. Men and Masculinities, 11(1), 86-103.

Carlsson, C. (2013). Masculinities, Persistence, and Desistance. Criminology, 51(3), 661-693. https://doi.org/10.1111/1745-9125.12016

Clemmer, D. (1958). The prison community. New York: Holt, Reinhart and Winston.

Collier, R. (1998). Masculinities, crime and criminology. Sage: London.

Connell, R. (1995). Masculinities. Polity,.

Connell, R. (2000). The men and the boys. Cambridge: Polity.

Connell, R., \& Messerschmidt, J. W. (2005). Hegemonic masculinity: Rethinking the concept. Gender \& Society, 19(6), 829-859.

Copes, H., Brookman, F., \& Brown, A. (2013). Accounting for Violations of the Convict Code. Deviant Behavior, 34(10), 841-858. https://doi.org/10.1080/01639625.2013.781444

Crewe, B. (2009). The prisoner society: Power, adaptation and social life in an English prison. Oxford: OUP, Clarendon.

De Viggiani, N. (2012). Trying to be something you are not: Masculine performances within a prison setting. Men and Masculinities, 1097184X12448464.

Earle, R. (2011). Boys' zone stories: Perspectives from a young men's prison. Criminology \& Criminal Justice, 11(2), 129-143. https://doi.org/10.1177/1748895811398458

Evans, T., \& Wallace, P. (2008). A prison within a prison? The masculinity narratives of male prisoners. Men and Masculinities, 10, 484-507.

Fazel, S., Ramesh, T., \& Hawton, K. (2017). Suicide in prisons: An international study of prevalence and contributory factors. The Lancet Psychiatry, 4(12), 946952. https://doi.org/10.1016/S2215-0366(17)30430-3

Fine, M., Weis, L., Addelston, J., \& Marusza, J. (1997). (In) Secure Times: Constructing White Working-Class Masculinities in the Late 20th Century. Gender \& Society, $11(1), \quad$ 52-68. https://doi.org/10.1177/089124397011001004

Goffman, E. (1969). The presentation of self in everyday life. London: Allen Lane. (1272570029).

Gooch, K. (2017). 'Kidulthood': Ethnography, juvenile prison violence and the transition from 'boys' to 'men.' Criminology \& Criminal Justice. https://doi.org/10.1177/1748895817741519

Gramsci, A. (1971). Selections from the prison notebooks of Antonio Gramsci. New York: International.

Hobbs, D. (1997). Professional Crime: Change, Continuity and the Enduring Myth of the Underworld. Sociology, 31(1), 57-72. https://doi.org/10.1177/0038038597031001005

Hood-Williams, J. (2001). Gender, masculinities and crime: From structures to psyches. Theoretical Criminology, 5(1), 37-60.

Irwin, J. (1970). The Felon. Prentice Hall.

Irwin, J., \& Cressey, D. (1962). Thieves, convicts and Inmate culture. Social Problems, 10, 142-155. 
Jefferson, T. (2002). Subordinating hegemonic masculinity. Theoretical Criminology, $6(1), 63-88$.

Jewkes, Y. (2005). Men Behind Bars. Men and Masculinities, 8, 44-63.

Kupers, T. A. (2001). Rape and the prison code. In D. F. Sabo, T. A. Kupers, \& W. London (Eds.), Prison masculinities. Philadelphia: Temple University Press.

Levins, A., \& Crewe, B. (2015). 'Nobody's better than you, nobody's worse than you': Moral community among prisoners convicted of sexual offences. Punishment \& Society, 17(4), 482-501. https://doi.org/10.1177/1462474515603803

Morris, T., \& Morris, P. d. (1963). Pentonville: A sociological study of an English prison. Routledge \& Kegan Paul.

Phillips, C. (2012). The multicultural prison: Ethnicity, masculinity, and social relations among prisoners. Oxford: Oxford University Press.

Ricciardelli, R. (2015). Establishing and asserting masculinity in Canadian penitentiaries. Journal of Gender Studies, 24(2), 170-191. https://doi.org/10.1080/09589236.2013.812513

Ricciardelli, R., Maier, K., \& Hannah-Moffat, K. (2015). Strategic masculinities: Vulnerabilities, risk and the production of prison masculinities. Theoretical Criminology, 1362480614565849 . https://doi.org/10.1177/1362480614565849

Sabo, D. F., Kupers, T. A., \& London, W. (Eds.). (2001). Prison masculinities. Philadelphia: Temple University Press.

Segal, L. (2007). Slow Motion: Changing Masculinities, Changing Men (3rd Edition edition). Basingstoke: Palgrave Macmillan.

Sim, J. (1994). Tougher than the rest? Men in prison. In T. Newburn \& E. A. Stanko (Eds.), Just boys doing business?: Men, masculinities and crime. Routledge: London.

Sloan, J. (2012). 'You Can See Your Face in My Floor': Examining the Function of Cleanliness in an Adult Male Prison. The Howard Journal of Criminal Justice, $51,400-410$.

Sykes, G. (2007). The society of captives: A study of a maximum security prison. NJ: Princeton University Press.

Toch, H. (1998). Hypermasculinity and prison violence. In Lee H Bowker (Ed.), Masculinities and violence. Thousand Oaks, CA: Sage Publications.

Trammell, R. (2009). Values, rules, and keeping the peace: How men describe order and the inmate code in California prisons. Deviant Behavior, 30(8), 746-771.

Tynan, R. R. (2019). Young Men's Experiences of Long Term Imprisonment: Living Life. London: Routledge.

\section{Notes}

\footnotetext{
${ }_{1}^{1}$ Prisoners might be segregated from the main location under two categories: 1) a disruptive prisoner might be segregated and placed in isolation under 'good order and discipline' (GOD); 2) the segregation of Vulnerable Prisoners for their own interest. Unlike segregation for GOD, this is not a form of punishment that limits privileges, but rather a duty to keep vulnerable prisoners safe on specialist wings or units.

${ }^{2}$ For children who are deemed to be too disruptive for mainstream schooling there are a number of alternative types of provision that can be tried before they are permanently excluded. This can include residential or boarding schools or day centres.

${ }^{3}$ Those who run up debts - for things like tobacco or drugs - that they cannot pay.

${ }^{4}$ To whom the others looked, or first and second in charge.

${ }^{5}$ Prison cell.
} 